\title{
Smallholder Farmers' perception and adaptation to climate variability and change in Fincha sub-basin of the Upper Blue Nile River Basin of Ethiopia
}

\author{
Israel Tessema $\mathbb{D} \cdot$ Belay Simane
}

Published online: 17 February 2020

(C) The Author(s) 2020

\begin{abstract}
Climate variability and change make agricultural sector a risky venture for smallholders' farmers. This paper presents an assessment of smallholder farmers' perceptions of climate variability and change, associated impacts on agricultural sector and the adaptive responses given in Fincha'a sub-basin of the Blue Nile River Basin of Ethiopia. We interviewed 380 head of households selected through systematic random sampling from eight Kebeles, two each from highland, midland, wetland, and lowland agro-ecosystems. Furthermore, focus group discussion and key informant interviews also performed to supplement and substantiate the quantitative data. Descriptive statistics used to summarize quantitative data and $\chi^{2}$ tests used to measure significance. The result revealed that increased temperature, frequency and severity of extreme weather events (drought and flood), and overall change in seasonality of rainfall over the last 20 years is a widely held perception. The associated impacts on agriculture include decline in length of growing period, the decreased and variability of water
\end{abstract}

I. Tessema $(\bowtie) \cdot$ B. Simane

Center for Environment and Development, College of

Development Studies, Addis Ababa University,

Addis Ababa, Ethiopia

e-mail: israel.tessema@aastu.edu.et

I. Tessema

Environmental Engineering, College of Biological and Chemical Engineering, Addis Ababa Science \&

Technology University, Addis Ababa, Ethiopia availability, increased crop damage by insects, pests, disease and weeds. In response, farmers practiced different adaptation measures like modification in crop and livestock production practices, and investment in land and water management activities at household and community level. The study also revealed the presence of multiple barriers that hindered the adoption of adaptation measures. To meet the impending challenges, situate by climate variability and change the adaptation measures implemented until now is not adequate. There is also extrication between farmers' perceptions of climate variability and change, and actual adaptation level. Despite significant number of farmers' perceived changes in temperature (about 93\%) and rainfall (about 88\%), the number of farmers adopted certain adaptation measures are below average. These necessitate the need for planned interventions to identify and support effective adaptation measures.

Keywords Climate change - Perception ·

Adaptation · Adaptation barriers · Fincha'a sub-basin

\section{Background}

Climate variability and change coupled with substantial threats for society and nature. To reduce these threats, adaptation and mitigation are the two possible 
societal response options (Intergovernmental Panel on Climate Change [IPCC] 2014; Füssel 2007). In the climate change context, adaptation is the process of adjustment to actual or expected climate and its effects in order to either lessen or avoid harm or exploit beneficial opportunities and mitigation is the process of reducing emissions or enhancing sinks of greenhouse gases (IPCC 2014). The two possible options (mitigation and adaptation) cannot substitute with each other rather complementary to each other (IPCC 2014; Füssel 2007). The already surfaced impact of climate change possibly addressed only through adaptation because it is difficult to reverse the already changed climate condition by mitigation. However, mitigation activity undertaken now has a reduction power in the long-term requirement of adaptation. Undoubtedly, climate change could impair economic growth of the nations and other facets of societal and natural wellbeing if the required adaptive measures not well taken now (Ethiopian Panel of Climate Change [EPCC] 2015; IPCC 2014; Chambwera and Stage 2010).

Historically, farmers have always attempted to adapt to the changing environmental condition of the agricultural systems. The attempt of the farmers to adapt becomes sometime successful and other time vain. Therefore, adaptation to changing climate condition by farmers has been the norm rather than the exception (EPCC 2015; Below et al. 2010; Füssel 2007; Adger 2003). However, the current speed of climate change is inducing and modifying known variability patterns beyond the coping capacity of systems (FAO 2008). As a prerequisite for adaptation, awareness by society about the changing condition of the climate required (Tripathi and Mishra 2016). Different scholars argued the importance of knowing the perception of the local people about the changing condition of the climate to facilitate the adaptation process (Nega et al. 2015; Tiwari et al. 2014; Woldeamlak 2012; Woldeamlak and Dawit 2011). Perceptions of climate change may affect how people will respond and adapt to its multiple impacts (Woldeamlak 2012). Concurrently, for someone to take action to adapt to climate change autonomously, he has to recognize climate change first. It is thus important to have some understanding about the perception of climate change by people residing in Fincha'a sub basin.

Therefore, this study aims to comprehend the agroecosystem based perception, impact, adaptive responses and barriers to adaptation of smallholder farmers in the study area. Agroecosystem used as a unit of analysis because this particular study wants to capitalize the variations among the AES in a broader geographical area. The specific objectives were to (1) examine the perception of smallholder farmers' and the impact of climate variability and change on agriculture, (2) describe the adaptive response of farmers to climate variability and change, and (3) identify the major barriers for adoption of adaptation measures. The study area identified as one of the erosion hot spot area, vulnerable and least researched parts of the Blue Nile River Basin of Ethiopia. The findings of the study provide context-specific contribution to the agro-ecosystem based understanding of the perception and adaptation responses.

\section{Literature review}

Conceptually, Climate variability is a variation in the climate system over short time scales such as months, years or decades and Climate change is conceptualized as longer-term trends in mean climate variables of periods of decades or longer (IPCC 2014; Watson 2001). Similarly, Adaptation is the adjustment in natural or human systems in response to actual or expected climatic stimuli or their effects, which moderates harm or exploits beneficial opportunities. Whereas, Adaptive capacity is the ability of systems, institutions, humans, and other organisms to adjust to potential damage, to take advantage of opportunities, or to respond to consequences (IPCC 2014).

Agroecosystems are ecological systems modified by human beings to produce food, fiber or other agricultural products (Conway 1987). It is an intersection of a set of agriculturally relevant climatic factors; soils and physiographic variables relevant to crop production; and a prevailing set of cropping practices. Agroecosystems are fundamentally different from natural ecosystems because they are human constructs and as such managed for agricultural goals (Rapport 2004).

Broadly, agricultural adaptation to climate change studied either at macro- or micro-levels (Kandlikar and Risbey 2000). The macro-level focuses on agricultural production systems adjustments at national and regional levels, whereas the micro-level concerned with farm level adjustments and decisionmaking (Nhemachena and Hassan 2007; 
Kurukulasuriya and Rosenthal 2003; Kandlikar and Risbey 2000; Risbey et al. 1999). Based on the intent, adaptation divided into autonomous (private/collective) and/or planned (policy decision/public sector) (EPCC 2015; Füssel 2007). Considering time of response as a category adaptation might be proactive (adaptation that takes place before impacts are observed) or reactive (adaptation that takes place after impacts of climate change already observed) (IPCC 2007b).

Ethiopian economy is driven by agriculture despite the issue of high rainfall variability that leads to frequent drought and severe land degradation (EPCC 2015; Conway and Schipper 2011; World Bank 2010; Diao and Pratt 2007). The sector contributes about $38.5 \%$ of the Gross Domestic Product (GDP), $85 \%$ of the employment, $90 \%$ of the export earnings, and $80.2 \%$ of the populations' earnings coming from this sector; and hence the prime contributing sector to food security (World Bank 2008; MoFED 2010; Central Statistical Agency [CSA] 2013; National Planning Commission [NPC] 2016).

According to the National Adaptation Program of Action (NAPA), the foremost-predicted impacts of climate change on Ethiopia's agriculture include dry spells and frequent droughts, reduced growing season, and increased occurrence of pests and diseases (National Metrological Agency [NMA] 2007). The same report also identifies drought and floods are the two major weather extreme events, and agriculture and food security are the sectors impacted most. Ethiopia frequently cited as a highly vulnerable country and the major underlying vulnerability factor is the heavy dependence of the economy on climate sensitive rainfed agriculture system (Paul and Weinthal 2018; Arragaw and Woldeamlak 2016; EPCC 2015; Conway and Schipper 2011; World Bank 2010).

Studies have shown that smallholder farmers in different parts of Ethiopia are facing different climate variability and change related problems. Such problems include reduced or variable rainfall, warming of temperatures, change in length of growing seasons, crop and livestock pests and diseases, weed problems, flooding, shortage of water and land degradation (Arragaw and Woldeamlak 2017; Wagesho et al. 2013; Woldeamlak 2012). The impact of climate variability and change contributes to reduced agricultural productivity, and without sound adaptation strategies by farmers, jeopardized the future sustainability of the sector in the area (Popoola et al. 2017; Arragaw and Woldeamlak 2016).

To overcome the problem, reported adaptation measures practiced by smallholder farmers of Ethiopia include crop/livestock diversification, soil and water conservation, planting trees, changing planting dates, and irrigation (Gebrehiwot and van der Veen 2013; Tessema et al. 2013; Woldeamlak 2012; Woldeamlak and Dawit 2011; Amdu 2010; Temesgen et al. 2009). Similarly, the most frequently cited barrier to adaptation include lack of information on adaptation options, land shortage, money shortage, labor shortage, lack of access to fertilizer, insecure land tenure, poor market access and poor potential for irrigation (Gebrehiwot and van der Veen 2013; Tessema et al. 2013; Amdu 2010; Temesgen et al. 2009).

\section{Study area}

\section{Biophysical setting}

Fincha' a sub-basin is one of the eighteen sub-basins of the Blue Nile River basin. The Ethiopian part of Blue Nile River basin also called Abbay River Basin and located in the northwestern region of Ethiopia. The Abbay River Basin has sixteen sub basins, which covers a total surface area of about $199,812 \mathrm{Km}^{2}$ (Denekew and Bekele 2009). The study sub basin specifically covered an area of about $4089.5 \mathrm{~km}^{2}$ and located in the south-central part of the Abbay River Basin, western-central Ethiopia (Fig. 1). The altitude of the sub basin ranges approximately between 836 and 3209 masl.

The average annual rainfall of the sub basin is about $1678 \mathrm{~mm} /$ year. About $73 \%$ of the annual rainfall of the sub basin falls between June and September. The average annual maximum and minimum temperature of the sub basin is about $24.8^{\circ} \mathrm{C}$ and $11.5{ }^{\circ} \mathrm{C}$ respectively.

\section{Socioeconomic setting}

The Fincha'a sub-basin administratively locate,d in Oromia regional state, Horo Guduru Wollega Zone of Horo, Guduru, Hababo Guduru, Abay Chomen, Jima Geneti, Jima Rare, and Jardega Jarte Districts. According to the Central Statistical Authority (CSA) (2013), the total population of the sub basin in 2017 


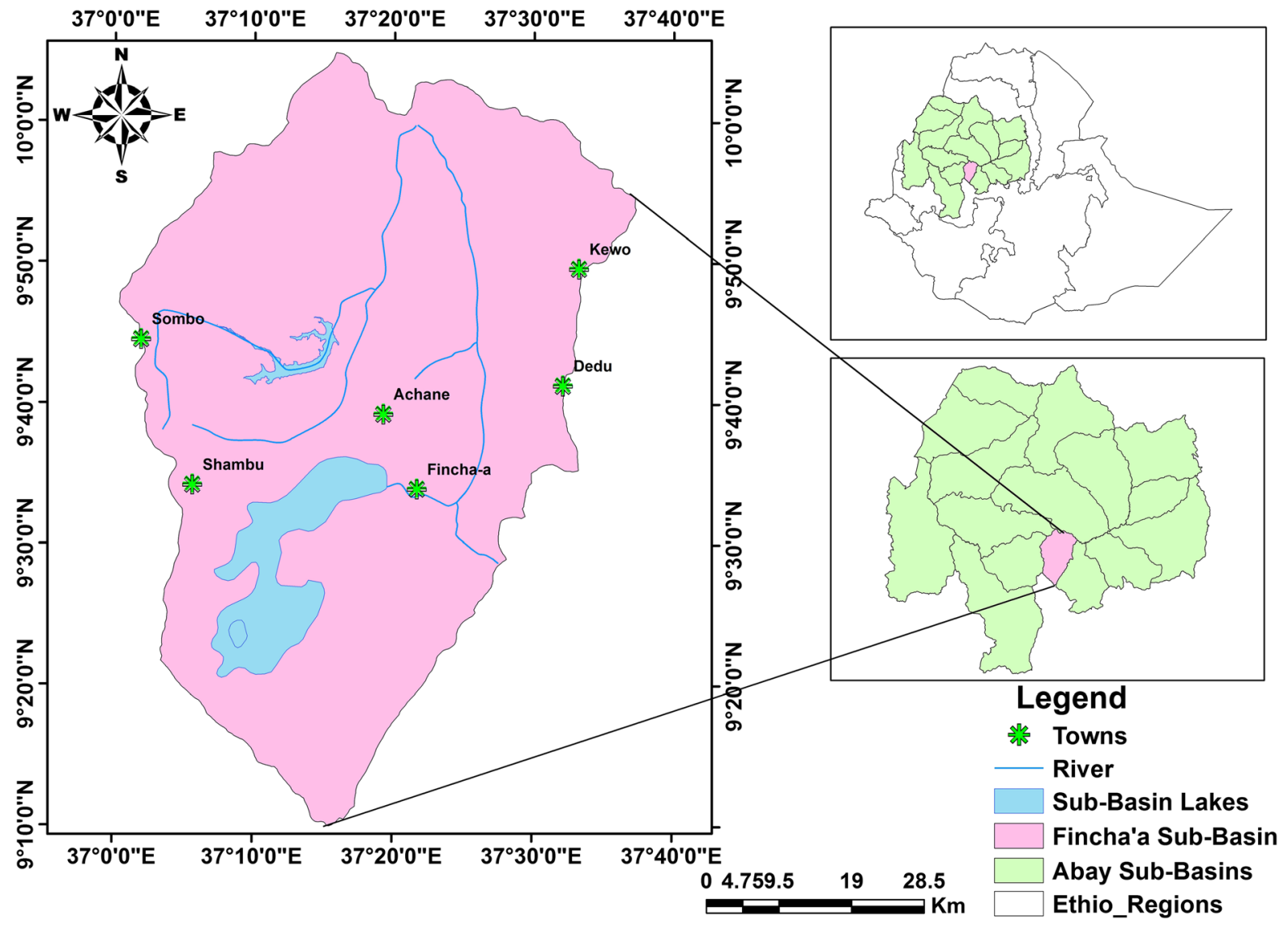

Fig. 1 Fincha'a Sub Basin and its associated Blue Nile/Abbay River Basin

assumed 577,467 and the average density of the population are about 153 people per $\mathrm{km}^{2}$. Densities are highest on the plateau and ridges of the sub basin.

Mixed crop-livestock agriculture is the main economic stay of the people of the sub basin. The result of the analysis of the sub basin revealed that there are four agro-ecosystems (Highland, Midland, Wetland and Lowland) within the sub basin. This gives an opportunity for the cultivation of range of crops like Wheat (Triticum aestivum and T. durem) and Barley (Hordeum vulgare) in the highland, Teff (Eragrostis tef) and Maize (Zea mays) in the midland and wetland, and Maize (Zea mays) and Sorghum (Sorhum bicolor Moench) in the lowland agro-ecosystem. There are also other cereal, pulse, oilseed, and vegetables crops grown in the sub basin.

The farming system in the sub basin dominated by cereal production that accounts for about $75 \%$ of the total cultivated area. From cereals: teff, wheat, and maize account $30.9 \%, 23.6 \%$, and $19.9 \%$ respectively.
Most cereal crops particularly teff and wheat are planted on fine seedbed and provided little groundcover during the most erosive storms in July and early August. This combined with steeply sloping upland area and poor land management practices contributes to land degradation currently observed in the area. Even though overall crop productivity in the sub-basin is increasing, the average productivity of different crops is much less than the potential productivity (Table 1).

\section{Methodology}

Data collection and method of analysis

The study employed a multi-stage sampling procedure to select the District, Kebeles ${ }^{1}$ and households from

\footnotetext{
$\overline{1}$ The lowest tiers in the administrative structure of the country.
} 
Table 1 Comparison of the average yield and potential attainable yield of major crops in the sub-basin. Source: Survey result; Zonal \& District agricultural Offices

\begin{tabular}{lllll}
\hline Crop & Proportion $(\%)$ & Current yield (T/ha) & Potential yield (T/ha) & Yield gap (\%) \\
\hline Maize & 15 & 3.11 & 4.5 & 30.9 \\
Teff & 23.3 & 0.90 & 2.0 & 55 \\
Wheat & 17.7 & 1.83 & 3.5 & 47.7 \\
Barley & 9.0 & 1.6 & 2.2 & 27.3 \\
Niger seed & 7.4 & 0.55 & 0.6 & 8.3 \\
Faba bean & 5.9 & 1.02 & 2.0 & 49 \\
Average & & 1.5 & 2.5 & 40 \\
\hline
\end{tabular}

the most general level (areas having similar agroecosystem) to the most precise level (household). In the first stage, the sub basin divided into similar agroecosystems based on the overlay of three inputs: an agro-climatic zoning based on precipitation and temperature, a soil and terrain analysis, and a map of the distribution of farming systems (Table 2). Based on the analysis four agro-ecosystems (Highland, Midland, Wetland and Lowland) identified in the subbasin (Fig. 2). In the second stage, the seven Districts found in the sub basin grouped into possible agroecosystems and three representative Districts (Horo, Jima Genete and Hababo Guduru) that represent the four agro-ecosystems selected randomly. The significance was to enable the research to focus on similarity and differences in vulnerability and adaptation strategy, depend on local context and circumstances, to climate variability and change on specific agroecosystem. Then, two kebeles selected randomly for each agro-ecosystem from the selected Districts. A systematic random sampling method employed for the selection of respondent household heads. The sampling frame (list of households residing in the Kebele) used for selection of households obtained from kebele administration.

Finally, 380 randomly sampled households selected living in eight Kebeles (two Kebeles in each AES), 95 households from each agro-ecosystem, participated in cross sectional survey. The detailed survey questionnaire generated household level data on household socio-demographic characteristics, perceptions of climate change, perceived impacts of climate change on agricultural production, adaptive responses employed and barriers to implement adaptation measures to current climate variability and change. To augment the quantitative information obtained from household survey, focus group discussions [FGD] (two from each agro-ecosystem) and key informant interviews [KII] with individual farmers (two from each agroecosystem) undertaken by using semi-structured checklists to generate additional in-depth qualitative information. The timeframe considered to assess climate change perceptions was the past two decades. The fieldwork carried out from May to June 2017.

To analyze the data descriptive statistical method that comprises percentages, means and frequencies

Table 2 Fincha'a sbu-basin Agro-ecosystems and their characteristics

\begin{tabular}{|c|c|c|c|c|}
\hline $\begin{array}{l}\text { Agro-ecosystem } \\
\text { (AES) }\end{array}$ & Farming systems & $\begin{array}{l}\text { Traditional climatic } \\
\text { zone }\end{array}$ & Major soils & Major crops \\
\hline Highland & $\begin{array}{l}\text { Semi-intensive Barley-Wheat } \\
\text { based }\end{array}$ & Dega & Leptosols & \\
\hline Luvisols & Barley, Wheat, Fave Bean & & & \\
\hline Midland & Intensive Tefff-Maize based & Upper Weyna Dega & Leptosols & \\
\hline Nitosols & Teff, Maize, Niger seed & & & \\
\hline Wetland & Intensive Tefff-Maize based & Lower Weyna Dega & Nitosols & Teff, Maize \\
\hline Lowland & Sorghum-based extensive & Upper Kola & $\begin{array}{l}\text { Luvisols } \\
\text { Vertisoil }\end{array}$ & $\begin{array}{l}\text { Sorghum, Teff, } \\
\text { Sesame }\end{array}$ \\
\hline
\end{tabular}




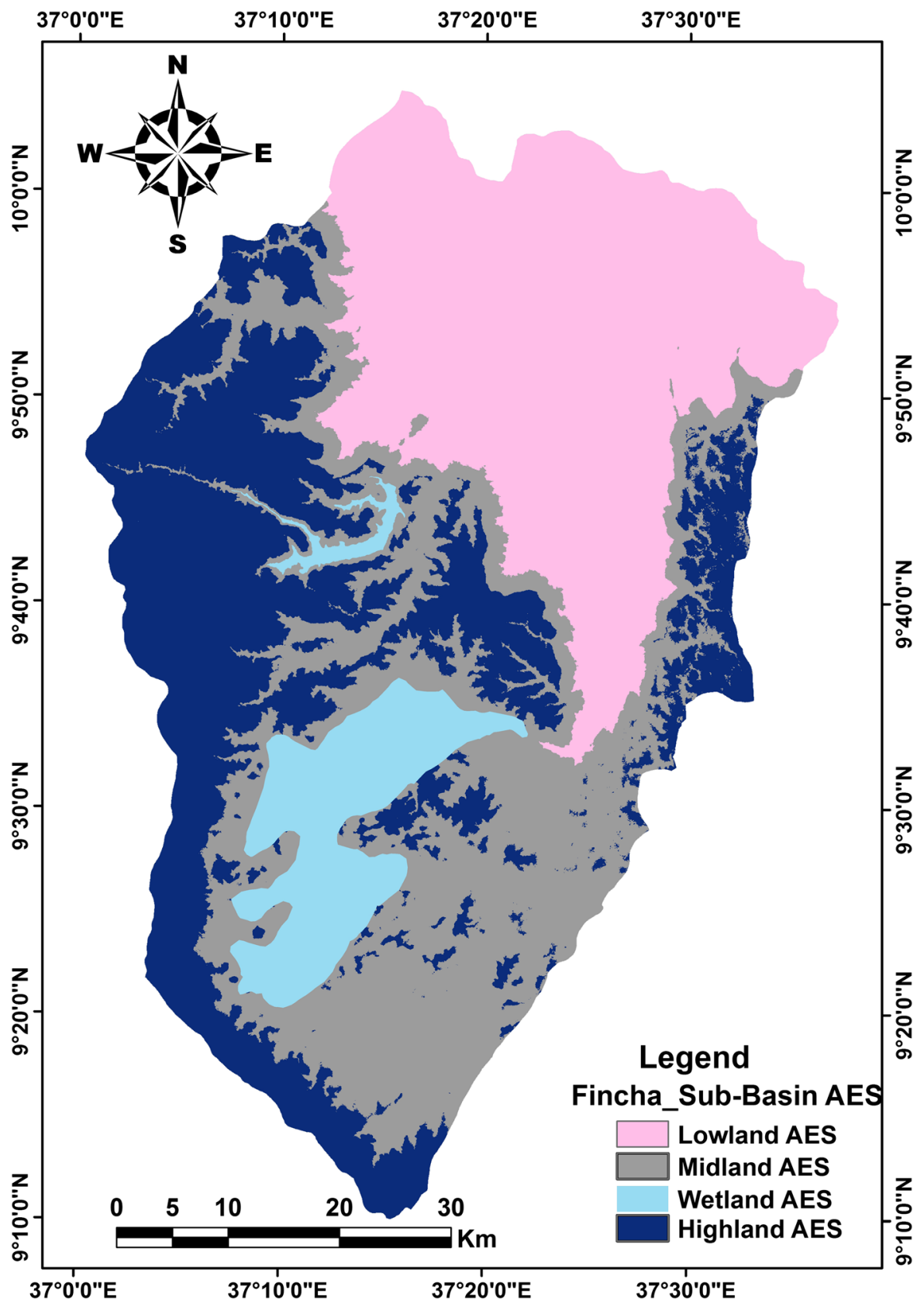

Fig. 2 Agro-ecosystems (AES) of Fincha'a Sub Basin

employed to summarize quantitative data on climate variability and change perceptions, impacts, adaptation strategies, and barriers to adaptation. Chi square test $\left(\chi^{2}\right)$ also used to test the statistical significance of variations across the four agro-ecosystems. Qualitative data used to augment and substantiate the quantitative analyses. The statistical software packages SPSS (statistical package for social scientists) and MS EXCEL used for data management and analysis.

Composite Index of Adoption (CIA) developed by Barungi and Maona (2011)used to know the intensity of adoption of adaptation strategies. These help to understand the variation in utilizing technologies and 
Table 3 Characteristics of the study population $(n=380)$ Source: Field Survey, 2017

\begin{tabular}{llr}
\hline Characteristics & Category & $\%$ \\
\hline \multirow{2}{*}{ Gender } & Male Headed Households & 92.9 \\
& Female Headed Households & 7.1 \\
& $15-30$ & 28.7 \\
& $31-65$ & 68.4 \\
Marital status & $>65$ & 2.9 \\
& Single & 4.2 \\
& Married & 91.6 \\
& Divorced & 1.05 \\
Education & Widowed & 3.15 \\
& Illiterate & 37.1 \\
& Reading \& Writing & 37.9 \\
& Primary School & 16.6 \\
& Secondary School \& above & 8.4 \\
Religion & Orthodox & 54.7 \\
& Protestant & 36.8 \\
& Wakefetta & 7.4 \\
& Muslims & 0.8 \\
& Catholic & 0.3 \\
& Oromo & 96.6 \\
& Amhara & 3.4 \\
\hline
\end{tabular}

for effective formulation of adaptation strategies. CIA computed as follows

$\mathrm{CIA}=\frac{\sum_{t=1}^{t=n}\left(\frac{T_{a}}{T}\right)}{N}$

where Ta denotes the total number of coping or adaptation strategies used by a farmer; $\mathrm{T}$ denotes the total number of coping or adaptation strategies available; $\mathrm{N}$ denotes the sample size and $\mathrm{Ta} / \mathrm{T} / \mathrm{N}$ represents the index of adoption for a household.

\section{Results and discussion}

Farmers' perceptions of local climate variability and change and its impacts

\section{Demographic characteristics of the respondents}

Table 3 presents the demographic characteristics of sampled households in terms of gender, age composition, marital status, education level, religion, and ethnic background.

\section{Farmers' perceptions of local climate variability and change}

Of the different climatic change parameters, respondents asked about their observations of local changes in temperature, precipitation, and climatic extreme events (drought and flooding) over the past two decades. In terms of temperature changes, about $92.9 \%$ (standard deviation of $6.6 \%$ among agroecosystems) of the total respondents perceived that the temperature has increased with significant difference among households in the four agro-ecosystems. In terms of total annual rainfall $87.9 \%$ (standard deviation of $11.5 \%$ among agro-ecosystems) of the total respondents perceived that, the total annual rainfall has decreased with significantly different at $1 \%$ level of significance across agro-ecosystems. About $88.7 \%$ believed that there is overall change in seasonality of rainfall; $85.6 \%$ experience drought extreme weather event; and $87.9 \%$ experience flooding extreme weather events in the past 20 years (Table 4). Findings from focus group discussions and key informant interview also substantiate the information from survey results. The findings of focus group discussion summarized below.

FGD in AES: As we heard from our forefathers and even in the past as elders mentioned, it is clear that the rain was so generous. Temperature increasing year by year, the rain usually used to come on time and rarely interrupts in a season, and the recurrence of drought increased.

Farmers' perception of increased temperature is consistent with what reported in the National Adaptation Plan of Action $\left(0.37{ }^{\circ} \mathrm{C}\right.$ every ten years) and Ethiopian Panel of Climate Change that the average temperature in the country increased for the last five decades $\left(0.2{ }^{\circ} \mathrm{C}\right.$ per decade $)$. Conversely, the perceived decline in rainfall does not show decreasing records in many parts of the country rather show variability (EPCC 2015; NMA 2007). KIIs \& FGDs unanimously witnessed increasing trends of temperature. Regarding rainfall, the discussants raised different views: all participants agreed the change in rainfall pattern but there are diverse views among the participants in overall amount of rainfall. Some argued total 
annual amount increased and many others said decreased. The difference is mostly associated with the variation in agro-ecosystem. The results are compatible with similar findings of farmers' perception of increased temperature and decreased rainfall reported by earlier studies conducted in other parts of the country (Getachew et al. 2018; Woldeamlak 2012; Woldeamlak and Dawit 2011; Aklilu and Alebachew 2009; Temesgen et al. 2008).

Study conducted in the Amhara National Regional State of Ethiopia (Menz Mama Midir District) reported similar findings of perceived increased temperature and decreased annual rainfall from study covered 90 households in three rural Kebeles (Woldeamlak 2012). Similarly, in a study conducted in Abay and Baro-Akobo river basins of Ethiopia, $82 \%$ and $96 \%$ perception of the respondents reported increased in temperature and decreased in annual rainfall respectively from 500 households in five sample Districts (Woldeamlak and Dawit 2011). Furthermore, in a study conducted in the southern lowlands of Ethiopia out of the 359 respondents $93 \%$ and $88 \%$ of them perceived increased mean temperatures and decreased annual rainfall respectively (Aklilu and Alebachew 2009).

Studies conducted in other parts of Africa have also shown a similar trend of an increase in temperature and decrease in precipitation of the climate change parameters. For instance, studies conducted in $10 \mathrm{sub}-$ Saharan African countries by World Bank on perceptions of an adaptation to climate change that covered over 9500 smallholder farmers found that significant numbers of farmers across 10 countries believed average temperatures had increased (Maddison 2007). Similarly, study conducted in different parts of Kenya $(n=710)$ reported that $94 \%$ of the farmers perceived an increase in average temperatures and $88 \%$ perceived a decrease in average rainfall over the last 20 years (Bryan et al. 2011).

Generally, the people's perception of increased temperatures is consistent and shows similar result with meteorological records in many parts of the country (EPCC 2015; NMA 2007). According to the respondents, the frequency and severity of extreme weather events (drought and flood) increased in the study sub-basin. Over the past 20 years, on average

Table 4 Farmers' perceptions of local climate variability and change (\% of respondents)

\begin{tabular}{|c|c|c|c|c|c|c|}
\hline \multirow[t]{2}{*}{ Climate change factors } & \multicolumn{4}{|c|}{ Agro-ecosystems of the sub basin } & \multirow[t]{2}{*}{ Total } & \multirow[t]{2}{*}{$\chi^{2}$ value } \\
\hline & Highland & Midland & Wetland & Lowland & & \\
\hline \multicolumn{7}{|l|}{ Temperature } \\
\hline Increasing & 85.3 & 89.5 & 97.9 & 98.9 & 92.9 & $23.67 * *$ \\
\hline Decreasing & 8.4 & 4.2 & 1.1 & 0 & 3.4 & $\mathrm{Df}=6$ \\
\hline No change & 3.2 & 1.1 & 0 & 0 & 1.1 & \\
\hline I don't know & 3.2 & 5.3 & 1.1 & 1.1 & 2.6 & \\
\hline \multicolumn{7}{|l|}{ Precipitation (total annual) } \\
\hline Increasing & 21.1 & 5.3 & 10.5 & 0 & 35 & $36.06 * * *$ \\
\hline Decreasing & 72.6 & 91.6 & 87.4 & 100 & 87.9 & $\mathrm{Df}=6$ \\
\hline No change & 6.3 & 3.2 & 2.1 & 0 & 2.9 & \\
\hline Change in seasonality & 82.1 & 89.5 & 85.3 & 97.9 & 88.7 & $13.29 * * *$ \\
\hline \multicolumn{7}{|l|}{ Extreme events } \\
\hline $\begin{array}{l}\text { Experience of extreme weather event (drought) in the past } \\
20 \text { years }\end{array}$ & 76.8 & 94.7 & 77.9 & 93.7 & 85.6 & $22.2 * * *$ \\
\hline How frequent does drought occur in the past 20 years? & 2.81 & 1.5 & 1.88 & 3.58 & 2.4 & \\
\hline Experience of extreme weather event (flood) in the past 20 years & 76.8 & 91.6 & 91.6 & 91.6 & 87.9 & $14.6^{* * *}$ \\
\hline How frequent does flood occur in the past 20 years? & 2.95 & 1.53 & 5.49 & 3.02 & 3.3 & \\
\hline
\end{tabular}

**Significance at 0.05 probability levels

***Significance at 0.01 probability levels 
Box 1 Elderly key informant from Gitilo Najor Kebele (highland agro-ecosystem) about the perceived climatic and other changes

Mr File is a 61-year-old farmer (male) in highland agro-ecosystem. He has lived in the area all his life and is currently head of a family of seven household members. Over the past 20 to 30 years, he reported that he had observed the following climatic and related changes

Rainfall variability increased over the past years. Shift in the seasonal rainfall pattern, especially sudden interruption of rainfall by the end of the rainy season is a common phenomenon

Temperatures are increasing year by year, and in consequence crops like teff (Eragrostis abyssinica), noug (Guizotia abyssinica) and even maize (Zea mays) at the periphery that were not grown in the highland agro-ecosystem have now started growing

The incidence of disease and pest frequency increased, and consequently our crop production and productivity level affected highly

The number of people in the area is increasing and the per capita land holding of the farmers decreasing from time to time

each study households experience 2.4 times drought and 3.3times flooding. Similar finding reported by Mahoo et al. (2013) that states the frequency and severity of natural shocks has increased in recent years in Ethiopia (Box 1).

\section{Farmers' perceptions of climate variability and change impact on agriculture}

Table 4 presents respondents' observation of climate variability and change impact on crop and livestock production in the study sub-basin. Though there are variations among AES, more than $85 \%$ of farmers had observed decline in length of growing period during the main Kiremt season. The finding is compatible with Paul et al. (2013) who stated climate change scenarios and models suggest that many parts of Ethiopia are likely to experience a decrease in the length of growing period, and even the decrease is severe in some areas. Any change in the crop-growing period is a challenge as it considerably affects farmers' decisions on what and when to plant (Woldeamlak 2012). With statistically significant differences among the AES, about $41.6 \%$ of total respondents reported decline in water availability, while $39 \%$ believed that there was more variability in water availability.

Similarly, about $79 \%$ of respondents observed an increased incidence of crop damaged by disease, $93 \%$ respondents observed an increase incidence of crop damage by insects and pests, and $96 \%$ respondents observed the severity of weed infestation in crop fields as one of the manifestations of climate variability and change. As farmers confirmed during FGDs and KIIs, though, the problems of agricultural crop diseases, insects, pests, and weeds are an already existing problem in the study area; it is aggravated and increased in incidence over the past 20 years. With a statistically significant difference among the AES, about $68 \%$ of respondents reported an increase in the incidence of livestock diseases and the rest (32\%) observed no change in the occurrence of livestock diseases. During FGDs, shortage of livestock-feed raised as one major problem and farmers agreed, as the problem is shortage of grazing land rather than climate change.

The perception of the farmers residing in different AES, which is the reflections of local impacts, can vary with variations in agro-ecosystem conditions. A higher proportion of households in highland, midland, and wetland AES areas perceived changes in length of crop growing period as compared to the lowland AES. Change in water availability is higher in lowland AES as compared to the other AES being the difference is statistically significant at 0.01 probability level. The incidence of agricultural pests, diseases, and weeds are comparable being the difference is statistically significant. The shift in crop growing areas is higher in highland, midland, and wetland AES as compared to households in lowland AES, the difference being statistically significant. The incidence of livestock disease increased in lowland, midland, and wetland AES as compared to the highland AES. The result supports scientific predictions and evidence elsewhere that climate change impacts are more likely felt visibly in the climatically extreme areas (cold highland and dry lowland areas) compared to those in intermediate conditions (EPCC 2015). Generally, there was a statistically significant difference in the different indicators of climate change perceptions across the four AES (Table 5). 
Table 5 Perceived impact of climate variability and change on agriculture (\% of respondents)

\begin{tabular}{|c|c|c|c|c|c|c|c|}
\hline \multirow[t]{2}{*}{ Indicator } & \multirow[t]{2}{*}{ Response } & \multicolumn{4}{|c|}{ Agro-ecosystems of the sub-basin } & \multirow[t]{2}{*}{ Total } & \multirow[t]{2}{*}{$\chi^{2}$ value } \\
\hline & & Highland & Midland & Wetland & Lowland & & \\
\hline \multirow[t]{3}{*}{ Change in length of growing period } & Increase & 0 & 0 & 0 & 1.05 & 0.26 & $79.92 * * *$ \\
\hline & Decrease & 93.7 & 96.8 & 92.6 & 56.9 & 85.00 & $\mathrm{Df}=6$ \\
\hline & No change & 6.3 & 3.2 & 7.4 & 42.1 & 14.7 & \\
\hline \multirow[t]{4}{*}{ Change in water availability } & Increase & 6.3 & 0 & 28.4 & 0 & 8.7 & $159.65^{* * *}$ \\
\hline & Decrease & 18.9 & 52.6 & 29.5 & 65.3 & 41.6 & $\mathrm{Df}=9$ \\
\hline & More variable & 40.0 & 43.2 & 37.9 & 34.7 & 38.9 & \\
\hline & No change & 34.7 & 4.2 & 4.2 & 0 & 10.8 & \\
\hline \multirow[t]{3}{*}{ Change in crop disease } & Increase & 65.26 & 82.1 & 83.16 & 85.26 & 78.95 & $14.5^{6^{* *}}$ \\
\hline & Decrease & 0 & 0 & 0 & 0 & 0 & $\mathrm{Df}=6$ \\
\hline & No change & 34.74 & 17.9 & 16.84 & 14.74 & 21.05 & \\
\hline \multirow[t]{3}{*}{ Change in crop damage by insects and pests } & Increase & 82.1 & 100 & 91.58 & 100 & 93.42 & $33.69 * * *$ \\
\hline & Decrease & 0 & 0 & 0 & 0 & 0 & $\mathrm{Df}=6$ \\
\hline & No change & 17.9 & 0 & 8.42 & 0 & 6.58 & \\
\hline \multirow[t]{3}{*}{ Change in the problem of weeds } & Increase & 89.47 & 100 & 92.63 & 100 & 95.52 & $25.18 * * *$ \\
\hline & Decrease & 0 & 0 & 2.11 & 0 & 0.53 & $\mathrm{Df}=6$ \\
\hline & No change & 10.53 & 0 & 5.26 & 0 & 3.95 & \\
\hline \multirow[t]{2}{*}{ Any shift in suitable growing areas } & Yes & 100 & 76.84 & 80.0 & 0 & 64.21 & $240.3 * * *$ \\
\hline & No & 0 & 23.16 & 20.0 & 100 & 35.79 & $\mathrm{Df}=3$ \\
\hline \multirow[t]{3}{*}{ Change in livestock disease } & Increase & 42.11 & 78.95 & 69.47 & 82.11 & 68.16 & $43.38 * * *$ \\
\hline & Decrease & 0 & 0 & 0 & 0 & 0 & $\mathrm{Df}=6$ \\
\hline & No change & 57.89 & 21.05 & 30.53 & 17.89 & 31.84 & \\
\hline
\end{tabular}

*Significance at 0.10 probability levels

**Significance at 0.05 probability levels

$* * *$ Significance at 0.01

\section{Farmers' adaptive responses to climate variability and change}

The adaptive responses of the farmers to the perceived climate variability and change categorized into two broad categories of adjustments in crop and livestock production, and responses through natural resources management.

\section{Adaptive responses in crop and livestock production}

In the study area, where the total annual average precipitation volumes are relatively higher (about $1678 \mathrm{~mm}$ ), as farmers verified the greatest impacts on agricultural production are from changes in rainfall variability, such as prolonged periods of drought and changes in the seasonal pattern of rainfall. To overcome the challenges different types of adaptation measures have been used by farmers in crop and livestock production activities. Table 6 presents the adaptation measures implemented by smallholder farmers to overcome the challenges of climate variability and change in crop and livestock production system. The adaptation measures implemented in crop production includes: (1) using new crop varieties (50.8\% of the total respondents), (2) incorporation of crop residue (37.6\% of the respondents), (3) adjusting the agricultural calendar/dates of planting and harvesting (32.9\% of the respondents) and (4) use of early maturing crop varieties for the crops traditionally produced $(26.6 \%$ of the respondents). Despite the number of adaptors are relatively small, practices such as increased diversification of crops produced (25.8\% of the total respondents), use of drought tolerant crop varieties (20.5\% of the respondents), use of disease/ pest tolerant crop varieties (4.5\% of the respondents), 
Table 6 Adaptation measures in crop and livestock production (\% of respondents)

\begin{tabular}{|c|c|c|c|c|c|c|}
\hline Adaptation Measures & Highland & Midland & Wetland & Lowland & Total & $\chi 2$ value \\
\hline \multicolumn{7}{|l|}{ Crop } \\
\hline Crop diversification (Increasing the number of crops produced) & 37.9 & 46.3 & 13.7 & 5.3 & 25.8 & $56.38 * * *$ \\
\hline Using new crop varieties & 44.2 & 69.5 & 60 & 29.5 & 50.8 & $35.42 * * *$ \\
\hline Adjusting date of planting & 32.6 & 42.1 & 23.2 & 33.7 & 32.9 & $7.76^{*}$ \\
\hline Use of early maturing crop varieties & 17.9 & 29.5 & 14.7 & 44.2 & 26.6 & $26.04 * * *$ \\
\hline Use of drought tolerant crop varieties & 15.8 & 22.1 & 4.2 & 40.0 & 20.5 & $36.58 * * *$ \\
\hline Use of disease/pest tolerant crop varieties & 6.3 & 11.6 & 0 & 0 & 4.5 & $20.87 * * *$ \\
\hline Incorporation of crop residues & 17.9 & 44.2 & 40.0 & 48.4 & 37.6 & $22.45 * * *$ \\
\hline Planting high value fruit trees & 6.3 & 0 & 0 & 0 & 1.6 & $18.28 * * *$ \\
\hline \multicolumn{7}{|l|}{ Livestock } \\
\hline Livestock diversification (Increasing the type of animals kept) & 15.8 & 24.2 & 14.7 & 4.2 & 14.7 & $15.24 * *$ \\
\hline Changing the type of animals kept & 0 & 7.4 & 0 & 9.5 & 4.2 & $17.23 * * *$ \\
\hline Reducing the number of animals kept & 41.1 & 24.2 & 10.5 & 17.9 & 23.4 & $26.93 * * *$ \\
\hline Sale weak and old animals before the outbreak of long dry season & 49.5 & 55.8 & 12.6 & 30.5 & 37.1 & $46.59 * * *$ \\
\hline Keeping improved animals' breeds & 2 & 0 & 0 & 0 & 0.5 & 6.03 \\
\hline $\begin{array}{l}\text { Practicing improved animal feed production/planting trees for } \\
\text { animal feed }\end{array}$ & 8.4 & 14.7 & 0 & 0 & 5.8 & $26.84 * * *$ \\
\hline Moving with animals in search of pasture and water & 0 & 12.6 & 0 & 0 & 3.2 & $37.18 * * *$ \\
\hline
\end{tabular}

*Significance at 0.10 probability levels

**Significance at 0.05 probability levels

$* * *$ Significance at 0.01 probability levels

and planting high value fruit trees (1.6\% of respondents) had been practiced by smallholder farmers (Table 6). Such adaptation practices believed to increase the resilience against climate change, particularly for an increase in climate variability like prolonged periods of drought, and seasonal shifts in rainfall. It also maintains production under changing rainfall patterns, such as changes in the timing of rains or erratic rainfall patterns. In addition, adaptation measure like incorporation of crop residue improves soil fertility and water holding capacity of the soil (FAO 2009).

Measures implemented by farmers in the livestock sub-sector includes: (1) sale weak and old animals before the outbreak of long dry season $(37.1 \%$ of respondents), (2) reducing the number of animals kept (23.4\% of respondents), and (3) livestock diversification (14.7\% of respondents). Small number of farmers also practiced improved animal feed production/planting trees for animal feed (5.8\% of respondents), changed the types of animals kept from cattle to small ruminants (4.2\% of respondents), moved with animals in search of pasture (3.2\% of respondents), and kept improved animal breeds ( $0.5 \%$ of respondents) as an adaptation strategy. Significant statistical differences observed among the four agro-ecosystems in terms of almost all adaptation measures used (Table 6). Many authors including (Woldeamlak 2012; Bryan et al. 2011; FAO 2009; Temesgen et al. 2009) have mentioned the above widely used adaptation strategies in different parts of Ethiopia \& Africa.

\section{Adaptive responses through water and other natural resources}

Agricultural management practices that increase agricultural production and reduce production risk also tend to be support climate change adaptation as they increase agricultural resilience and reduce yield variability under climate variability and extreme events, which might intensify with climate change (Bryan et al. 2011). Such activities implemented both 
Table 7 Soil and water management measures used in individual farm (\% of respondents)
*** Significance at 0.01 probability levels

\begin{tabular}{lcccccc}
\hline Adaptation Measures & Highland & Midland & Wetland & Lowland & Total & $\chi 2$ value \\
\hline Crop rotation & 90.5 & 99 & 85.3 & 99.0 & 93.5 & $21.03 * * *$ \\
Intercropping & 17.9 & 23.2 & 11.6 & 32.6 & 21.3 & $13.41^{* * *}$ \\
Compost preparation & 26.3 & 24.2 & 7.4 & 49.5 & 26.9 & $43.48^{* * *}$ \\
Manure heaping & 29.5 & 21.1 & 11.6 & 0 & 15.6 & $34.89 * * *$ \\
Contour plowing & 100 & 94.7 & 92.6 & 95.8 & 95.8 & 6.79 \\
Irrigation practice & 31.6 & 16.8 & 42.1 & 0 & 22.6 & $54.53 * * *$ \\
Soil \& Stone bunds & 43.2 & 32.6 & 34.7 & 65.3 & 44.0 & $25.75^{* * *}$ \\
Water ways/Cut of drain & 43.2 & 9.5 & 42.1 & 33.7 & 32.1 & $32.11 * * *$ \\
Check Dam & 21.1 & 32.6 & 35.8 & 11.6 & 25.3 & $18.63 * * *$ \\
Planting trees & 35.8 & 29.5 & 37.9 & 76.8 & 45.0 & $53.36^{* * *}$ \\
\hline
\end{tabular}

at household and community levels to adapt to the changing climatic conditions and local environmental change more broadly. Management practices undertaken at household level include crop rotation, contour plowing, intercropping, manure preparation and application, and land management activities.

Of the different adaptation measures implemented at household level crop rotation and contour plowing activities practiced almost by the entire respondents. Out of the soil management activities that include intercropping, compost preparation, and manure heaping practiced by $21.3 \%, 26.9 \%$, and $15.9 \%$ of the total respondents respectively. Similarly, physical and biological soil and water conservation activities like soil and stone bunds, water way, check dams, and planting of trees carried out by $44 \%, 32.1 \%, 25.3 \%$, and $45 \%$ of the total respondents respectively. Irrigation practiced by about $22.6 \%$ of the respondents. In almost all of the conservation adaptation measures applied at household level, statistically significant different observed among the four agro-ecosystems (Table 7).

Likewise, community level interventions to create assets include physical and biological soil and water conservation measures, afforestation and reforestation activities, and river diversion activities for traditional small-scale irrigation activities. Among the total respondents' majority of them participated in the adaptation measures implemented at the community level: soil and water conservation (81.6\%) and afforestation/reforestation activities (78.4\%). The relative high number of household participation in community asset creation attributed by the fact that such adaptation measures coordinated and implemented by District and Kebele government officials as a planned adaptation strategy. Statistically significant difference observed among the four AES in participation of river diversion by the community (Table 8). The result revealed community participation in river diversion is higher in highland AES, where as nil in the lowland AES, which is simply the result of have no access to such irrigation schemes in this specific AES. This shows the prevailing agro-ecological conditions and available environmental resources influence options for agricultural adaptation.

Rainwater storage in the soil (in situ) or in any reservoir (ex situ) is widely promoted adaptation option to climate change in Ethiopia and elsewhere in

Table 8 Adaptation through water \& other natural resource management: community asset creation (\% of households)

\begin{tabular}{|c|c|c|c|c|c|c|}
\hline Adaptation Measures & Highland & Midland & Wetland & Lowland & Total & $\chi^{2}$ value \\
\hline Participating in soil and water conservation with community & 87.4 & 82.1 & 71.6 & 85.3 & 81.6 & $9.31 *$ \\
\hline Participating in afforestation/reforestation with the community & 76.8 & 86.3 & 78.9 & 71.6 & 78.4 & 6.28 \\
\hline Participating in river diversion with the community for irrigation & 40.0 & 16.8 & 18.9 & 0 & 18.9 & $49.89 * * *$ \\
\hline
\end{tabular}

*Significance at 0.10 probability levels

***Significance at 0.01 probability levels 
the world. However, it was hard to find such intervention in the study area. Water based intervention promoted as an adaptation strategy by smallholders' farmers because it offers a suitable means for upgrading rain-fed agriculture through in situ soil moisture conservation and on-farm runoff storage for complete and supplementary irrigation (Mahoo et al. 2013). Additionally, rainwater-harvesting techniques can prevent degradation of natural resources through reduced soil erosion especially in the fragile highland agro-ecosystems.

Asset creating collective action-based adaptation measures like watershed land and water management activities increases the resiliency of the systems. Once the resilience of the systems enhanced the adaptive capacity increased. Adaptive capacity means the whole of capabilities of systems, resources and institutions of a country/region to implement effective adaptation measures to varied changes (Smit and Pilifosova 2003; MEA 2005; IPCC 2014). Therefore, such type of measures should be encouraged and supported as a planned adaptation measure.

Generally, the adaptation measures implemented in the study area until now are not adequate to meet the impending challenges situate by climate variability and change. According to EPCC (2015), climate change has been happening and will continue to happen with severe impacts on crop and animal production as well as on food security and the national economy. Based on our observation of the area and as verified during FGDs there is high encroachment of agricultural land to the forest and grazing land use system in the area. These aggravated the land degradation problem found in the highland AES, and flooding and siltation problem in the wetland AES including the hydropower dams. Recent studies have shown that flood hazard is increasing in the highland areas due to changes in land use/land cover, rainfall pattern, and drainage (Kassa et al. 2014). Therefore, any planned adaptation approach implemented in the area should incorporate forms of land use and land use change, and targeted payment for environmental services.

\section{Intensity of adoption of adaptation measures at the household level}

The sample households totally utilized 27 adaptation measures in response to the perceived climate variability and change. To know the intensity of adoption of adaptation measures, composite index of adoption (CIA) computed by utilizing the total number of adaptations measure a single farmer practiced from the possible available options. The adaptation measures implemented vary from AES to AES. The most widely practiced adaptation measure in all the AESs is contour plowing $(96 \%)$ followed by crop rotation (94\%). The least implemented adaptation measures are keeping improved animal breeds $(1 \%)$ and planting high value fruit trees $(2 \%)$ found only in the highland AES. Of the total adaptation strategies identified in the sub-basin (27), the actual implemented strategies by farmers range from 3 to 15 and the overall mean is 8.7. This shows that the intensity of adoption of adaptation measures by farmers in the subbasin is below average. Adaptation is a process and its outcome affected by many factors and widely varies between countries, communities, and over time. Factors that influence adaptation of smallholder farmers include farmers' characteristics, extension services, social networks, financial services, and technological factors. These groups of factors are not only influencing adaptation but also responsible for difference choices of adaptation strategies and behaves differently in different countries and regions depending on the level of development (Rass 2006).

When we evaluate the sub-basin based on percentage of farmers practicing certain type of adaptation measures, on average $32 \%$ of farmers adopted certain adaptation measures. The value is higher $35 \%, 34 \%$, and $33 \%$ for midland, highland, and lowland AESs respectively. Whereas, the corresponding value for the lowland AES is below the average (27\%). Relatively, farmers found in the midland AES implemented higher number of adaptation strategies from the available list of options. The calculated value of CIA for midland, highland, lowland, and wetland AESs were $0.36,0.34,0.32$, and 0.26 respectively. The CIA value is higher for midland AES and lower for wetland AES as compared to the other AESs. Although, the surveyed farmers at least practiced three adaptation strategies, the overall result of the finding verifies that the adoption of the adaptation measures is below average.

From the result, one can conclude that there is extrication between farmers' perceptions of climate variability and change, and actual adaptation level. Despite significant number of farmers' perceived 
Table 9 Barriers affecting adaptation to climate variability \& change (\% of respondents)

\begin{tabular}{lllllll}
\hline Adaptation Barrier & \multicolumn{2}{l}{ Agro-ecosystems } & & \multirow{2}{*}{ Mean } & \multirow{2}{*}{$\chi^{2}$ value } \\
\cline { 2 - 5 } & Highland & Midland & Wetland & Lowland & \\
\hline Lack of knowledge \& Information & 71.6 & 61.1 & 77.9 & 88.4 & 74.8 & $19.85^{* * *}$ \\
Lack of modern agricultural inputs & 65.3 & 58.9 & 67.4 & 80.0 & 67.9 & $10.19 * *$ \\
Labor shortage & 67.4 & 44.2 & 35.8 & 71.6 & 54.8 & $35.0^{* * *}$ \\
Low potential for irrigation & 29.5 & 50.5 & 18.9 & 92.6 & 47.9 & $121.2^{* * *}$ \\
Lack of finance & 49.5 & 41.0 & 40.0 & 58.9 & 47.3 & $8.87 *$ \\
Lack of technical support & 18.9 & 14.7 & 22.1 & 30.5 & 21.6 & $7.51^{*}$ \\
\hline
\end{tabular}

* Significance at 0.10 probability levels

**Significance at 0.05 probability levels

***Significance at 0.01 probability levels

changes in temperature (about 93\%) and rainfall (about $88 \%$ ), the number of farmers adopted certain adaptation measures are below average. The finding supports some previous study conducted in Ethiopia (Temesgen et al. 2009; Bryan et al. 2009). According to Temesgen et al. (2009), almost half of their surveyed farmers in the Nile Basin of Ethiopia ( $n=1000)$ did not attempt to adapt to climate change and variability. Similar result also obtained by Bryan et al. (2009) in which $37 \%$ of respondents did not adapt to perceived climate change. Whereas study conducted by Arragaw and Woldeamlak (2017) in central highlands of Ethiopia revealed that more than $63 \%$ adapted certain adaptation measures.

\section{Barriers to adaptation}

Barriers are the interaction of complex of factors that influence adaptation. According to Islam et al. (2014), barriers that hamper adaptation are a function of "the people involved, the nature of the specific systems involved and/or the larger context in which the people and systems operate". On the other way Biesbroek et al. (2013) views barriers as factors and conditions that emerge from the actor, the governance system or the system of concern. From this, it is apparent that barriers are the interaction of complex of factors that influence adaptation. Respondents in the study area mentioned many factors that hindered them in the adoption of adaptation measures. Among which knowledge and information are the most frequently cited barrier in the study area $(75 \%)$. Other barriers include lack of insufficient supply of modern agricultural inputs (like improved seed, fertilizer, and crop protection inputs) (68\%), labor shortage (55\%), low potential for irrigation (48\%), lack of finance $(47 \%)$, and lack of technical support (22\%).

During FGDs, farmers raised the issue of free grazing animals for the low level of adoption of biological and physical soil and water conservation measures. Lack of adequate information and technical support is another area that farmers broadly speaking about for lack of effective adaptation strategies. This implies that farmers in the area requires to raise their level of awareness about changes of the climate condition, implement controlled grazing and create the possibility of better access to technologies to cope with the changes and/or adapt to it. Statistically significant differences observed among the four agroecosystems in terms of almost all adaptation barriers (Table 9). Similar studies conducted in other parts of the country obtained almost similar results despite the difference in the order of their influence that vary across the areas (Getachew et al. 2018; Arragaw and Woldeamlak 2017; Temesgen et al. 2009).

\section{Conclusion and recommendation}

Ethiopia as a country suffers a lot from climate variability and change, and upcoming change in climate constitutes a major development challenge. Therefore, understand the nature of climate change impacts, farmers perception of these changes and 
indigenous adaptation practices at local levels have pare amount importance to design and implement appropriate adaptation strategies at local and household levels. This particular study examined farmers' perception of climate variability and change, the impact of climate variability and change on agriculture sector, adaptation measures taken by smallholder farmers and barriers faced during the course of adaptation in four agro-ecosystems of the Fincha'a sub-basin. It is evident that the majorities of farmers in the sub-basin are aware of warmer temperatures and changes in rainfall patterns and overall decrease of the annual total rainfall. Farmers' perception of increased temperature and changes in rainfall pattern evidenced by metrological data, whilst decreased in annual total rainfall not proofed. The main impact of the change on crop and livestock production as reported by respondents include decline in length of growing period, the decreased and variability of water availability, increased crop damage by insects and pests, increased infestation of weeds, and increased incidence of livestock disease.

To respond to these changes, farmers have adopted a range of measures like crop diversification, planting different crop varieties, changing planting and harvesting dates to correspond to the changing pattern of rainfall, irrigation, implementing different land management measures, and different biological and physical soil conservation measures. The adaptation measures implemented until now are not adequate to meet the impending challenges situate by climate variability and change. There is also extrication between farmers' perceptions of climate variability and change, and actual adaptation level. Despite significant number of farmers' perceived changes in temperature and rainfall, the number of farmers adopted certain adaptation measures are below average. The finding also revealed the presence of multiple barriers that hindered the adoption of available adaptation measures.

These necessitate that there is a need for planned interventions to identify and support effective adaptation measures. Some of the possible interventions include increase the awareness of the community to avert their information and knowledge barriers, and increase their predictive capacity by government and non-governmental organizations, investments in integrated natural resources management by government and non-governmental organizations, dissemination of improved and suitable crop varieties, agro-ecosystem specific in situ and ex situ rainwater harvesting technique, crop diversification, and integrated pest control are some to mention. It is also obvious that such interventions should build on farmers' knowledge by following farmer-participatory processes.

Acknowledgements We would like to thank all those individuals and organizations who provided us with valuable information. In addition, we extend our gratitude for the enumerators who were involved in generating all the required data at the field level.

Authors' contributions IT and BS generated the idea and designed the study. Israel carried out the data collection, data analysis, and write-up. Belay provided statistical assistance, read, and revised the manuscript. Finally, both authors read and approved the final version of the manuscript.

Funding The data collection, data analysis and write-up of the study supported by Addis Ababa University, and Addis Ababa Science and Technology University.

Availability of data and materials Data sharing not applicable to this article as no datasets generated or analyzed during the current study.

\section{Compliance with ethical standards}

Conflict of interest The authors declare that they have no conflict of interest.

Open Access This article is licensed under a Creative Commons Attribution 4.0 International License, which permits use, sharing, adaptation, distribution and reproduction in any medium or format, as long as you give appropriate credit to the original author(s) and the source, provide a link to the Creative Commons licence, and indicate if changes were made. The images or other third party material in this article are included in the article's Creative Commons licence, unless indicated otherwise in a credit line to the material. If material is not included in the article's Creative Commons licence and your intended use is not permitted by statutory regulation or exceeds the permitted use, you will need to obtain permission directly from the copyright holder. To view a copy of this licence, visit http://creativecommons.org/licenses/by/4.0/.

\section{References}

Adger, W. N. (2003). Social capital, collective action, and adaptation to climate change. In Voss M. (Ed.), Der Klimawandel. VS Verlag fürSozialwissenschaften. https://doi. org/10.1007/978-3-531-92258-4_19.

Aklilu, A., \& Alebachew, A. (2009). Assessment of climate change-induced hazards, impacts and responses in the 
southern lowlands of Ethiopia. Forum for Social Studies, report No. 4.

Amdu, B. (2010). Analysis of farmers' perception and adaptation to climate change and variability: The case of Choke Mountain, East Gojjam. MA thesis. Department of Environment and Development, Addis Ababa University.

Arragaw, A., \& Woldeamlak, B. (2016). Local climate variability and crop production in the central highlands of Ethiopia. Environmental Development, 19(2016), 36-48. https://doi.org/10.1016/j.envdev.2016.06.002.

Arragaw, A., \& Woldeamlak, B. (2017). Smallholder farmers' coping and adaptation strategies to climate change and variability in the central highlands of Ethiopia. Local Environment. https://doi.org/10.1080/13549839.2017. 1290058.

Barungi, M., \& Maona, B. (2011). Adoption of soil management technologies by smallholder farmers in central and southern Malawi. Journal of Sustainable Development in Africa, 12(3), 28-38.

Below, T., et al. (2010). Micro-level practices to adapt to climate change for African small-scale farmers. IFPRI Discussion Paper No. 953. Washington, DC: International Food Policy Research Institute.

Biesbroek, G. R., Klostermann, J. E. M., Termeer, C. J. A. M., \& Kabat, P. (2013). On the nature of barriers to climate change. Regional Environmental Change, 13(5), 1119-1129. https://doi.org/10.1007/s10113-013-0421-y.

Bryan, E., Ringler, C., Okoba, B., Roncoli, C., Silvestri, S., \& Herrero, M. (2011). Adapting agriculture to climate change in Kenya: household and community strategies and determinants. Research Report. Washington, DC: World Bank.

Bryan, E., et al. (2009). Adaptation to climate change in Ethiopia and South Africa: options and constraints. Environmental Science \& Policy, 12(4), 413-426.

Chambwera, M., \& Stage, J. (2010). Climate change adaptation in developing countries: Issues and perspectives for economic analysis. www.iied.org/pubs/display.php?o= 1551711ED.

Conway, D., \& Schipper, E. L. F. (2011). Adaptation to climate change in Africa: Challenges and opportunities identified from Ethiopia. Global Environmental Change, 21(1), 227-237. https://doi.org/10.1016/j.gloenvcha.2010.07. 013.

Conway, G. R. (1987). The properties of agroecosystems. Agricultural Administration, 24, 95-117.

CSA, Central Statistical Agency. (2013). Population projection of Ethiopia for all regions at Woreda level from 2014 to 2017. Addis Ababa: The Federal Democratic Republic of Ethiopia.

Denekew, A., \& Bekele, S. (2009). Characterization and Atlas of the Blue Nile Basin and Its Sub Basins. Addis Ababa: International Water Management Institute.

Diao, X. A., \& Pratt, N. (2007). Growth options and poverty reduction in Ethiopia-An economy-wide model analysis. Food Policy, 32(2), 205-228.

EPCC, Ethiopian Panel on Climate Change. (2015). First assessment report, Working Group II Agriculture and Food Security, Published by the Ethiopian Academy of Sciences.
FAO, Food and Agriculture Organization. (2008). Climate-related trans-boundary pests and diseases including relevant aquatic species. Expert meeting. Rome: FAO.

FAO, Food and Agriculture Organization. (2009). Food security and agricultural mitigation in developing countries: Options for capturing synergies. Rome: FAO.

Füssel, H. M. (2007). Adaptation planning for climate change: Concepts, assessment approaches, and key lessons. Sustainable Science, 2(2), 265-275. https://doi.org/10.1007/ s11625-007-0032-y.

Getachew, T., Degefa, T., \& Negussie, S. (2018). Perception and adaptation strategies of rural people against the adverse effects of climate variability: A case study of Boset district, East Shewa Ethiopia. Environmental Development. https:// doi.org/10.1016/j.envdev.2018.07.005.

Gebrehiwot, T., \& van der Veen, A. (2013). Climate change vulnerability in Ethiopia: disaggregation of Tigray region. Journal of Eastern African Studies, 7(4), 607-629.

IPCC, Intergovernmental Panel on Climate Change. (2007b). Climate change 2007: Impacts, adaptation and vulnerability, working group II contribution to the fourth assessment report of the intergovernmental panel on climate change. Cambridge, United Kingdom.

IPCC, Intergovernmental Panel on Climate Change. (2014). In Core Writing Team, R. K. Pachauri, \& L. A. Meyer (Eds.) Climate change: Synthesis report. The contribution of working groups I, II and III to the fifth assessment report of the intergovernmental panel on climate change. IPCC, Geneva.

Islam, M. M., Sallu, S., Hubaceck, K., \& Paavola, J. (2014). Limits and barriers to adaptation to climate variability and change in Bangladeshi coastal fishing communities. Marine Policy, 43, 208-216. https://doi.org/10.1016/j.marpol. 2013.06.007.

Kandlikar, M., \& Risbey, J. (2000). Agricultural impacts of climate change: If adaptation is the answer, what is the question? Climatic Change, 45(529-539), 2000.

Kassa, T., Anton, V. R., Jean, P., Simon, V. B., Jozef, D., \& Kassa, A. (2014). Spatial analysis of land cover changes in eastern tigray (Ethiopia) from 1965 to 2007: Are there signs of a forest transition? Land Degradation and Development. https://doi.org/10.1002/ldr.2275.

Kurukulasuriya, P., \& Rosenthal, S. (2003). Climate change and agriculture: A review of impacts and adaptations, climate change series 91. Environment Department Papers. Washington, DC: The World Bank.

Maddison, D. (2007). The perception of and adaptation to climate change in Africa. Policy research working paper No. 4308. World Bank, Washington, DC.

Mahoo, H., Raden, M.Y., Kinyangi, J., \& Cramer, L. (Eds.) (2013). Climate change vulnerability and risk assessment of agriculture and food security in Ethiopia: Which way forward? CCAFS Working Paper no. 59. CGIAR research program on climate change, Agriculture and Food Security (CCAFS). Copenhagen, Denmark. www.ccafs.cgiar.org.

MEA, Millennium Ecosystem Assessment. (2005). Ecosystems and human well-being: Wetlands and water synthesis, 2005. Washington, DC: World Resources Institute.

MoFED, Ministry of Finance and Economic Development. (2010). Growth and transformation plan. Ethiopia: Addis Ababa. 
Nega, D., Mohammed, C., Bridle, K., Corkrey, R., \& McNeil, D. (2015). Perception of climate change and its impact by smallholders in pastoral/agro-pastoral systems of Borana, South Ethiopia. SpringerPlus, 4(1), 236. https://doi.org/10. 1186/s40064-015-1012-9.

Nhemachena, C., \& Hassan, R. (2007). Micro-level analysis of farmers' adaptation to climate change in Southern Africa. IFPRI Discussion Paper No. 00714, Washington, DC.

NMA, National Meteorological Agency. (2007). Climate Change National Adaptation Program of Action (NAPA) of Ethiopia. Addis Ababa. https://unfccc.int/resource/docs/ napa/eth01.pdf.

NPC, National Planning Commission, Federal Democratic Republic of Ethiopia. (2016). Growth and Transformation Plan II (2015/2016-2019/2020). Main Text, Volume 1, Addis Ababa. http://dagethiopia.org/new/images/DAG_ DOCS/GTP2_English_Translation_Final_June_21_2016. pdf. Retrieved on September 12, 2018.

Paul, C. J., \& Weinthal, E. (2018). The development of Ethiopia's Climate Resilient Green Economy 2011-2014: Implications for rural adaptation. Climate and Development. https://doi.org/10.1080/17565529.2018.1442802.

Paul, E., Nicholas, Y., \& Jonathan, B. (2013). How will climate change spatially affect agriculture production in Ethiopia? Case studies of important cereal crops. Climatic Change. https://doi.org/10.1007/s10584-013-0776-6.

Popoola, P. P., Monde, N., \& Yusuf, S. F. G. (2017). Perceptions of climate change impacts and adaptation measures used by crop smallholder farmers in Amathole district municipality, Eastern Cape province, South Africa. GeoJournal. https://doi.org/10.1007/s10708-017-9829-0.

Rapport, D. J. (2004). Ecosystem health and ecological integrity: Foundations for sustainable futures. In B. Mitchell (Ed.), Resource and environmental management in Canada (pp. 24-53). Don Mills, ON: Oxford University Press.

Rass, N. (2006). Policies and Strategies to address vulnerability of pastoralists in Sub-Saharan Africa. Pro-poor Livestock Initiative. PPLPI working paper 37, p. 102.

Risbey, J., Kandlikar, M., Dowlatabadi, H., \& Graetz, D. (1999). Scale, context, and decision making in agricultural adaptation to climate variability and change. Mitigation Adaptation Strategies Global Change, 4(2), 137-165. https:// doi.org/10.1023/A:1009636607038.

Smit, B., \& Pilifosova, O. (2003). From adaptation to adaptive capacity and vulnerability reduction. In J. B. Smith, R. J. T. Klein, \& S. Huq (Eds.), Climate change, adaptive capacity and development. London: Imperial College Press.

Temesgen, D., Hassan, R. M., Ringler, C., Tekie, A., \& Mahmud, Y. (2009). Determinants of farmers' choice of adaptation methods to climate change in the Nile Basin of Ethiopia. Global Environmental Change, 19(2), 248-255. https://doi.org/10.1016/j.gloenvcha.2009.01.002.

Temesgen, D., Hassan, R.M., Tekie, A., Mahud, Y., \& Ringler, C. (2008). Analyzing the determinants of farmers' choice of adaptation methods and perceptions of climate change in the Nile Basin of Ethiopia. IFPRI Discussion Paper No. 00798, IFRI, Washington, DC.

Tessema, Y. A., Aweke, C. S., \& Endris, G. S. (2013). Understanding the process of adaptation to climate change by smallholder farmers: the case of East Hararghe zone, Ethiopia. Agricultural and Food Economics, 1(1), 13. https://doi.org/10.1186/2193-7532-1-13.

Tiwari, K. R., Rayamajhi, S., Pokharel, R. K., \& Balla, M. K. (2014). Determinants of the climate change adaptation in rural farming in Nepal Himalaya. International Journal of Multidisciplinary and Current Research, 2(March/April 2014), 234-240.

Tripathi, A., \& Mishra, A. K. (2016). Knowledge and passive adaptation to climate change: An example from Indian farmers. Climate Risk Management. https://doi.org/10. 1016/j.crm.2016.11.002.

Wagesho, N., Goel, N., \& Jain, M. (2013). Temporal and spatial variability of annual and seasonal rainfall over Ethiopia. Hydrological Sciences Journal, 58(2), 354-373.

Watson, R. T. (2001). Climate change: Synthesis report: Contribution of Working Groups I, II, and III to the Third Assessment Report of the Intergovernmental Panel on Climate Change. Cambridge: Published for the IPCC by Cambridge University Press.

Woldeamlak, B. (2012). Climate change perceptions and adaptive responses of smallholder farmers in central highlands of Ethiopia. International Journal of Environmental Studies, 69(3), 507-523.

Woldeamlak, B., \& Dawit, A. (2011). Farmers' perceptions of climate change and its agricultural impacts in the Abay and Baro-Akobo River Basins, Ethiopia. Ethiopian Journal of Development Research, 33(1), 1-28.

World Bank. (2008). Ethiopia Agriculture and Rural Development Public Expenditure Review 1997/1998-2005/2006. Report No. 41902-ET. World Bank: Washington, DC.

World Bank. (2010). Ethiopia: Economics of adaptation to climate change. Synthesis report. Washington, DC.: World Bank. https://openknowledge.worldbank.org/handle/ 10986/12504.

Publisher's Note Springer Nature remains neutral with regard to jurisdictional claims in published maps and institutional affiliations. 